\title{
Wykaz publikacji Jubilata
}

\section{Rok 1970}

1. Charakter prawny norm pracy, „Studia Prawno-Ekonomiczne” 1970, t. V, ss. 61-85.

\section{Rok 1971}

2. Karno-prawna ochrona praw pracownika, „Państwo i Prawo” 1971, z. 2 (300), ss. 322-331 (współautor S. Lelental).

\section{Rok 1972}

3. Normy pracy. Problematyka prawna, PWN, Warszawa 1972, ss. 186.

\section{Rok 1975}

4. Odpowiedzialność majątkowa pracowników według kodeksu pracy, „Sprawozdania z Czynności i Posiedzeń Naukowych ŁTN", R. XXIX, nr 6, ss. 1-7.

5. Rola umowy w ustalaniu wynagrodzenia za prace, "Studia Prawnicze” 1975, z. 2 (44), ss. 43-93.

6. Świadczenia z zakładowego funduszu nagród, „Praca i Zabezpieczenie Społeczne” 1975, nr 8/9, s. 28.

\section{Rok 1978}

7. Glosa do uchwały SN z 21 X 1977 r. I PZP 38/77 [dotycząca wynagrodzenia za prace w godzinach nadliczbowych], "Orzecznictwo Sądów Polskich i Komisji Arbitrażowych” 1978, poz. 160.

8. Glosa do wyroku SN z 19 I 1977 r. I PRN 99/76 [dotycząca czasu pracy], „Orzecznictwo Sądów Polskich i Komisji Arbitrażowych" 1978, poz. 46.

9. Glosa do wyroku SN z 10 III 1977 r. I PR 205/76. [dotycząca wynagrodzenia za pracę], „Orzecznictwo Sądów Polskich i Komisji Arbitrażowych” 1978, poz. 100. 


\section{Rok 1979}

10. Glosa do uchwały SN z 18 X 1977 r. I PZP 23/77 [dotycząca wynagrodzenia za czas niewykonywania pracy z powodu przeszkód leżących po stronie zakładu pracy], „Nowe Prawo" 1979, nr 10, s. 165-167.

11. La protection de l'enfant - rapport polonais, "Travaux de l'Association Henri Capitant" 1979 , t. XXX, ss. 549-558.

12. Socjalnyje prawa dietiej i ochrana truda niesowierszennoletnich po polskomu trudowomu prawu, "Sovriemiennoje Polskoje Pravo" 1979, nr 4, s. 39-54.

13. Wybrane problemy społeczno-prawne stosunków pracy we Francji, „Studia Prawnicze” 1979, nr 3, s. 9-114.

\section{Rok 1980}

14. Glosa do wyroku SN z 28 III 1980 r. III URN 29/80 [dotycząca charakteru prawnego gratyfikacji jubileuszowej], „Orzecznictwo Sądów Polskich i Komisji Arbitrażowych” 1981, poz. 213.

15. Rola prawa pracy w kształtowaniu należytej jakości pracy, „Studia Prawno-Ekonomiczne” 1980, t. XXIV, s. 57-70.

\section{Rok 1981}

16. Glosa do uchwały SN z 19 IV 1979 r. I PZP 7/79 [dotycząca wynagrodzenia za pracę członka rady zakładowej], „Orzecznictwo Sądów Polskich i Komisji Arbitrażowych” 1981, poz. 94.

17. Glosa do uchwały SN z 2 X 1979 r. I PZP 36/79 [dotycząca wypłaty wynagrodzenia za pracę w obcej walucie], „,Orzecznictwo Sądów Polskich i Komisji Arbitrażowych” 1981, poz. 40.

18. Glosa do wyroku SN z 28 III 1980 r. III URN 29/80 [dotycząca charakteru prawnego gratyfikacji jubileuszowej], „Orzecznictwo Sądów Polskich i Komisji Arbitrażowych” 1981, poz. 213.

19. Jaki system płac w nauce, "Głos Nauczycielski” 1981, nr 48.

20. Międzynarodowe prawo pracy, red. M. Seweryński, „Acta Universitatis Lodziensis” 1981, Folia Iuridica 5, ss. 123.

21. Poszukiwanie modelu samorzadu, "Przegląd Związkowy” 1981, nr 7/8, s. 36-38.

22. Samorząd a zwiazki zawodowe, "Przegląd Związkowy” 1981, nr 9, s. 27-30, 35.

23. Wptyw konwencji i zaleceń Międzynarodowej Organizacji Pracy na prawo krajowe, „Acta Universitatis Lodziensis" 1981, Folia Iuridica 5, s. 97-121.

24. Wynagrodzenie za pracę. Pojęcie, regulacja i ustalanie, PWN, Warszawa 1981, ss. 272.

25. Zakres i kierunki nowelizacji kodeksu pracy, „Przegląd Związkowy” 1981, nr 6, s. 25-29.

\section{Rok 1982}

26. Glosa do uchwały SN z 16 XII 1981 r. I PZP 39/81 [dotycząca nagrody jubileuszowej], „Orzecznictwo Sądów Polskich i Komisji Arbitrażowych” 1982, poz. 226. 


\section{Rok 1983}

27. Konwencje MOP ratyfikowane przez Polskę, oprac. M. Seweryński, Warszawa 1983.

28. L'évolution de la législation sur l'autogestion des travailleurs en Pologne, „Revue internationale de droit comparé", Juillet-Septembre 1983, n³, ss. 463-495.

\section{Rok 1984}

29. Ewolucja samorzadu pracowniczego w Polsce, "Studia Prawno-Ekonomiczne" 1984, t. XXXII, s. 7-39.

30. Glosa do uchwały SN z 27 VII 1982 r. III PZP 37/82 [dotycząca uznania prowizji komornika za wynagrodzenie wypłacane z osobowego funduszu płac], „Orzecznictwo Sądów Polskich i Komisji Arbitrażowych" 1984, poz. 37.

31. Glosa do uchwały SN z 10 VI 1983 r. III PZP 25/83 [dotycząca stosowania świadczeń motywacyjnych w przedsiębiorstwach państwowych], „Orzecznictwo Sądów Polskich i Komisji Arbitrażowych" 1984, poz. 235.

32. Odpowiedzialność pracownicza, a wynagrodzenie za prace, [w:] Odpowiedzialność pracownicza, red. W. Sanetra, Materiały XI Zimowej Szkoły Prawa Pracy, Karpacz, marzec 1984, UWr., Wrocław 1984, ss. 79-81.

\section{Rok 1985}

33. Glosa do wyroku SN z 8 II 1984 r. I PR 5/84 [dotycząca wynagrodzenia za pracę], „Nowe Prawo" 1985, nr 9, s. 142-147.

34. La participation des travailleurs à la gestion de l'entreprise en droit polonais, "Acta Universitatis Lodziensis" 1985, Folia Iuridica 19, s. 103-127.

35. Metody regulacji prawnej wynagrodzenia za prace w krajach kapitalistycznych, IPiSS, Warszawa 1985, ss. 90.

36. Worker Participation in the Management of the Enterprise in Poland, "Managerial Law" 1985, Vol. 27, No 5, ss. 1-6.

\section{Rok 1986}

37. Przedsiębiorstwo państwowe i samorząd jego załogi. Komentarz. Aut.: C. Kosikowski, H. Lewandowski, A. Rembieliński, M. Seweryński. Stan prawny na 31.12.1986 r., PWN, Warszawa 1987, ss. 626. [Rec. T. B. Jaworski, „Rzeczpospolita” 1988, nr 65; B. Ziemianin, „Państwo i Prawo" 1988, nr 7, s. 128-131].

\section{Rok 1987}

38. Odpowiedzialność załogi zakładu pracy, [w:] Odpowiedzialność zbiorowych podmiotów prawa pracy. Materiały XIV Zimowej Szkoły Prawa Pracy. Karpacz, marzec 1987, red. W. Sanetra, UWr., Wrocław 1987, ss. 63-80. 


\section{Rok 1988}

39. Glosa do uchwały SN z 30.12.1986 r. III PZP 42/86 [dotycząca pojęcia wynagrodzenia za pracę], "Orzecznictwo Sądów Polskich i Komisji Arbitrażowych” 1988, poz. 195.

40. Międzynarodowe prawo pracy, IWZZ, Warszawa 1988, ss. 334 (współautor L. Florek).

41. Problemy samorządu społecznego, red. i wstęp M. Seweryński, UŁ, Łódź 1988, ss. 235.

42. Przemiany systemu regulacji prawnej wynagrodzenia za prace w Polsce pod wptywem reformy gospodarczej, [w:] Pravne aspekty hospodarskeho mechanizmu v socialistickej spolecnosti, Pravnicka Fakulta P. J. Safarika v Kosiciach, Kosice 1988, ss. 89-104.

43. Samorzad załogi a inne organizacje pracownicze w przedsiębiorstwie, [w:] Problemy samorzadu społecznego, red. i wstęp M. Seweryński, UŁ, Łódź 1988, ss. 91-117.

44. Selbstverwaltung der Werktätigen in Polen, [w:] Aktualne problemy konstytucyjne w RFN i PRL, red. H. Ridder, T. Szymczak. „Acta Universitatis Lodziensis” 1988, Folia Iuridica 36, ss. 189-212.

45. System regulacji prawnej wynagrodzenia za prace, [w:] Studia z prawa pracy [Dla uczczenia 50-lecia działalności prof. dra Wacława Szuberta], red. H. Lewandowski, PWN, Warszawa 1988, ss. 307-323.

\section{Rok 1989}

46. Grupowe formy organizacji pracy. Charakterystyka prawna, UŁ, Łódź 1989, ss. 70 (współautor Z. Góral).

47. Pojęcie i ideologia partycypacji pracowników w zarządzaniu przedsiębiorstwem kapitalistycznym. Zarys problematyki, „Studia Prawno-Ekonomiczne” 1989 [1990], nr 42, s. 35-60.

\section{Rok 1990}

48. Droga do wolności związkowej w krajach Europy Wschodniej, [w:] Uniwersytet Kościołowi łódzkiemu, red. M. Kamińska, Diecezjalne Wydawnictwo Łódzkie, Łódź 1990, s. $62-82$.

49. Glosa do wyroku SN z 16 XII 1988 r. I PRN 53/88 [dotycząca nagród jubileuszowych], „Orzecznictwo Sądów Polskich” 1990, poz. 173 c.

50. Koncepcja regulacji prawnej grupowych form organizacji pracy (współautor Z. Góral), [w:] Przestanki reformy prawa pracy, cz. 1. red. i wstęp Z. Salwa, MPiPS, Warszawa 1990, ss. $120-132$.

51. L'influence de la réforme économique sur le droit du travail en Pologne, [w:] Rapports Polonais présentés au Treizième Congrès International de Droit Comparé, Montréal, 18-24 VIII 1990, ed. Witold Czachórski, Ossolineum, KNP, Wrocław 1990, ss. 165-177.

52. Les problèmes de liberté et d'égalité dans le droit socialiste du travail : étude du cas polonais, dans: Liberté, Egalité, Fraternité. Actualités en droit social, Université Bordeaux I, Bordeaux 1990, ss. 183-193 (współautor L. Lewandowski).

53. Negocjacje zbiorowe w zarządzaniu przedsiębiorstwem kapitalistycznym, "Studia Prawno -Ekonomiczne" 1990 [1991], nr 44, s. 69-85.

54. Podstawy prawne organizowania się pracodawców, „Biuletyn Rady Legislacyjnej” 1990, nr 18, s. 81-93. 


\section{Rok 1991}

55. Les accords salariaux d'entreprise en Pologne, dans: Les accords d'entreprise. Zbiór studiów dedykowany Profesorowi Wactawowi Szubertowi. Wprowadzenie H. Lewandowski, "Acta Universitatis Lodziensis" 1991, Folia Iuridica 46, s. 93-107.

56. Samorządowe uprawnienia pracowników przedsiębiorstwa państwowego w Polsce, „Acta Universitatis Lodziensis" 1991, Folia Iuridica 45, ss. 131-150.

57. Założenia kodeksowej regulacji wynagrodzenia za pracę (tezy do dyskusji na forum Komisji ds. Reformy Prawa Pracy), [w:] Przesłanki reformy prawa pracy, cz. 2, red. i wstęp Z. Salwa, IPiSS, Warszawa 1990 [1991], ss. 5-18.

\section{Rok 1992}

58. Changements politiques et droit du travail. Perspective polono-espagnole. Symposium polonocatalan de droit comparé du travail Barcelone, 12-13 décembre 1991 r., red. M. Seweryński, A. Marzal. Allocution d'inauguration: A. Marzal. Réflexions finales: W. Szubert, A. Marzal, UŁ, Łódź 1992, ss. 205.

59. Evolution et perspectives de la participation des travailleurs dans la gestion de l'entreprise en Pologne, [w:] Changements politiques et droit du travail. Perspective polono-espagnole. Symposium polono-catalan de droit compare du Travail, Barcelone, 12-13 decembre 1991, red. M. Seweryński, UŁ, Łódź 1992, ss. 157-180.

60. Perspektywy partycypacji pracowników w zarzadzaniu przedsiębiorstwem w krajach zachodnich, „Studia Prawno-Ekonomiczne” 1992, nr 46, s. 7-32.

61. Układy zbiorowe pracy w okresie demokratycznej przebudowy państwa i gospodarki, „Państwo i Prawo" 1992, nr 12, s. 15-29.

\section{Rok 1993}

62. Udziat pracowników w organach przedsiębiorstwa kapitalistycznego, „Acta Universitatis Lodziensis" 1993, Folia Iuridica 58, s. 163-176.

\section{Rok 1994}

63. [Szubert Wacław. 1912-1994]. Wspomnienie pośmiertne, oprac. Henryk Lewandowski, Michał Seweryński, „Państwo i Prawo” 1994, nr 2, s. 89-91.

64. Kodeks pracy. Stan prawny na 20 IV 1994 r., oprac. Michał Seweryński, Zbigniew Hajn, Wydawnictwo „Park”, Bielsko-Biała 1994, ss. 561.

65. Les groupements - rapport polonais, dans: Travaux de l'Association Henri Capitant, t. XLV, 1994, ss. 627-645.

66. Los sindicatos en los paises poscomunistas. La legislacion, los problemas actuales, el futuro. ICADE, “Universidad Pontificia Comillas" 1994, n 32, s. 209-265.

67. Ocena stanu prawa oraz propozycje legislacyjne w dziedzinie stosunków pracy, ubezpieczeń społecznych i świadczeń, „Biuletyn Rady Legislacyjnej” 1994, nr 1, ss. 46-59 (współautor M. Szurgacz). 
68. Pologne, dans: Les conflits collectifs et leurs modes de règlement. Union Internationale des avocats. Congrès de Strasbourg 10-14 Septembre 1990, Kluver, Editions Juridiques Belgiques, Brussels 1994, s. 113-133.

\section{Rok 1995}

69. Centralisation et decentralisation des conventions collectives dans le droit polonais. Séminaire International du Droit Comparé du Travail, des Relations Professionelles et de la Sécurité Sociale, « Annaales 1995 », Université « Atilla Jósef »- Faculté de Droit, Szeged 1994, s. 137-149.

70. Ewolucja polskiego prawa pracy $i$ zbiorowych stosunków pracy w okresie postkomunistycznej transformacji, [w:] Polskie prawo pracy i zbiorowe stosunki pracy w okresie transformacji, red. M. Seweryński, Ministerstwo Pracy i Polityki Socjalnej, Biblioteka Dialogu Społecznego, Warszawa 1995, ss. 19-45.

71. Kodeks pracy. Ustawy zwiazane z kodeksem pracy, wzory pism zwiazanych ze stosunkiem pracy, przepisy wykonawcze, red. M. Seweryński, Z. Hajn, Wydawnictwo „Park”, Bielsko -Biała 1995.

72. Polish labour law and collective labour relations in the period of transformation, red. M. Seweryński, Publ. Ministry of Labour and Social Policy, Social Dialogue Library, Warszawa 1995, ss. 143.

73. Polskie prawo pracy i zbiorowe stosunki pracy w okresie transformacji, red. M. Seweryński, Ministerstwo Pracy i Polityki Socjalnej, Biblioteka Dialogu Społecznego, Warszawa 1995, ss. 145.

74. Problemy reprezentatywności w zbiorowych stosunkach pracy, „Państwo i Prawo” 1995, nr 9, ss. 3-13 (M. Pliszkiewicz - współautor).

75. Trade unions in the post-communist countries: regulations, problems and prospects, "Comparative Labor Law Journal", winter 1995, vol. 16, No 2, ss. 177-230.

76. Uwagi o kryteriach akademickości na tle sytuacji uczelni polskich, „Nauka Polska” [III/ XXVIII. Rocznik Kasy im. Józefa Mianowskiego] 1994, ss. 20-27.

77. Zbiorowe stosunki pracy w Polsce. Wypowiedzi: Elżbieta Sobótka, Ewa Lewicka, Michał Seweryński, Andrzej J. Wilk, Medard Masłowski, „Ekonomika i Organizacja Przedsiębiorstwa” 1995, nr 2, s. 3-7.

\section{Rok 1996}

78. Betriebsräte mit Streikrecht, „Arbeit und Recht“ 1996 Nr. 6, ss. 204-205.

79. Changes in Polish Labour Law and Industrial Relations During the Period of Post-Communist Transformation, [w:] Labour Law and Industrial Relations in Central and Eastern Europe (From Planned to Marked Economy), "Bulletin of Comparative Labour Relations" [Kluwer Law International] 1996, No 31, ss. 85-107.

80. Europejskie prawo pracy i ubezpieczeń społecznych, red. L. Florek, Warszawa 1996. Rec. Seweryński Michał, „Państwo i Prawo” 1997, nr 7, s. 89-90.

81. Kierunki nowelizacji kodeksu pracy, „Państwo i Prawo” 1996, nr 6, ss. 12-25.

82. Legal and Social Aspects of Industrial Relations in Central and Eastern Europe, [w:] Education for Transition to Market Economy in Countries of Central and Eastern Europe, eds K. Cichocki and P. Marer, Warszawa 1996, ss. 130-140. 
83. Legal Means of Counteracting Unemployment, [w:] Social and Economic Dilemmas of Old Industrial Regions. Conclusions for Parliament, Wydawnictwo Sejmowe, Warszawa 1996, ss. 216-229.

84. Les groupements dans la vie du travail. Rapport polonais, (dans) Les groupements. Travaux de l'Association Henri Capitant, t. XLV, 1994 [Journées japonaises. Litec 1996], ss. 627-645.

85. Les problèmes de la représentativité dans les relations collectives de travail, [w:] La représentativité des partenaires sociaux dans les relations collectives de travail, Ministère du Travail et de la Politique Sociale, Varsovie 1996, ss. 52-65 (współautor: M. Pliszkiewicz).

86. Les syndicats dans les pays postcommunistes: la législation, les problèmes actuels, l'avenir, [w:] Le syndicalisme contemporain et son avenir, Wydawnictwo Uniwersytetu Łódzkiego, Łódź 1996, ss. 155-206.

87. Prospects for the Development of Labour Law and Social Security Law in Central and Eastern Europe in the Twenty-first Century, [w:] $5^{\text {th }}$ European Regional Congress for Labour Law and Social Security, Leiden 1996, ss.1-17.

88. Prospects for the Development of Labour Law and Social Security Law in Central and Eastern Europe in the Twenty-First Century, "The International Journal of Comparative Labour Law and Industrial Relations", Winter 1996, vol. 18, No 2, ss. 182-203.

89. Status and functions of trade unions in Poland, [w:] New Patterns of Collective Labour Law in Central Europe, U. Carabelli, S. Sciarra, Giuffré Editore, Milano 1996, ss. 161-186.

90. Studia Prawno-Europejskie, red. M. Seweryński, Wydawnictwo Uniwersytetu Łódzkiego, Łódź 1996, ss. 122.

91. Studia Prawno-Europejskie, t. II, red. M. Seweryński, Wydawnictwo Uniwersytetu Łódzkiego, Łódź 1997, ss. 157.

92. Środki prawne przeciwdziałania bezrobociu, [w:] Dylematy społeczne i gospodarcze starego regionu przemysłowego. Wnioski dla Parlamentu, red. I. Lipowicz. Wydawnictwo Sejmowe, Warszawa 1996, ss. 205-217.

93. The Varieties in Employment Status and Related Issues in Polish Labour Law, [w:] The 24 ${ }^{\text {th }}$ International Symposium, "The National Academy of Sciences R.O.K." 1996, ss. 39-73.

94. Zwiazki zawodowe w krajach postkomunistycznych. Ustawodawstwo, problemy i perspektywy, [w:] Syndykalizm wspótczesny i jego przyszłość, Wydawnictwo Uniwersytetu Łódzkiego, Łódź 1996, ss. 163-211.

\section{Rok 1997}

95. The Government's Role in Industrial Relations During the Period of Transformation in Poland, [w:] Labour Law at the Crossroads: Changing Employment Relationships. Studies in Honour of Benjamin Aaron, Kluwer Law International, The Hague 1977, ss. 183-200.

96. Kodeks pracy. Ustawy zwiazane z kodeksem pracy, wzory pism zwiazanych ze stosunkiem pracy, przepisy wykonawcze, red. i wstęp M. Seweryński, Z. Hajn, Wydawnictwo „Park”, Bielsko-Biała 1997.

97. Varieties in Employment Status and Related Issues in Polish Labour Law, "The International Journal of Comparative Labour Law and Industrial Relations", Summer 1997, vol. 18, No 4, ss. 523-546. 


\section{Rok 1998}

98. Flexibilisation of Working Life, Potentials and Challenges for Labour Law, [w:] Rapports Polonais, s. 179-204 (Rapports Polonais présentés sur le Quinzième congrès international de droit comparé. (Bristol, 26 VII - 1 VIII 1998), red. Biruta Petrykowska-Lewaszkiewicz, UŁ, Łódź 1998, ss. 282.

99. Kodeks pracy. Ustawy zwiazane z kodeksem pracy, wzory pism zwiazanych ze stosunkiem pracy, przepisy wykonawcze, red. M. Seweryński, Z. Hajn, Wydawnictwo „Park”, Bielsko-Biała 1998.

100. Perspektywy rozwoju prawa pracy $i$ zabezpieczenia społecznego w krajach Europy Środkowej $i$ Wschodniej z uwzględnieniem integracji europejskiej, [w:] Studia Prawno-Europejskie, t. III, red. M. Seweryński [Wydawnictwo Uniwersytetu Łódzkiego, Łódź 1998], s. 34-54.

101. Studia Prawno-Europejskie, t. III, red. M. Seweryński, Wydawnictwo Uniwersytetu Łódzkiego, Łódź 1998, ss. 215.

\section{Rok 1999}

102. Collective Labour Law in Poland, "Japan International Labour Law Forum", Special Series No 7, March 1999, ss. 85.

103. Dialog społeczny. Wspótzależność gospodarki i prawa pracy, [w:] Referaty na VI Europejski Kongres Prawa Pracy i Zabezpieczenia Społecznego Warszawa, 13-17 IX 1999, Wydawnictwo Naukowe „Scholar”, Warszawa 1999, ss. 11-38.

104. Kodeks pracy. Ustawy zwiazane z kodeksem pracy, wzory pism zwiazanych ze stosunkiem pracy, przepisy wykonawcze, red. M. Seweryński, Z. Hajn, Wydawnictwo „Park”, 11 wyd., Bielsko-Biała 1999.

105. Lenkijos kolektyvines darbo teises evoliucionavimas po 1989 metu, Teise 33(1), Vilniaus Universiteto Leidykla, Vilnius 1999, ss. 52-66.

106. Polish Labour Law: From Communism to Democracy, Dom Wydawniczy ABC, Warszawa 1999, ss. 271.

107. Studia Prawno-Europejskie, t. IV, red. M. Seweryński, Wydawnictwo Uniwersytetu Łódzkiego, Łódź 1999, ss. 252.

108. Założenia nowej regulacji prawnej zbiorowych sporów pracy w Polsce, [w:] Ład społeczny $w$ Polsce $i$ w Niemczech na tle jednoczacej się Europy. Księga pamiątkowa poświęcona Czesławowi Jackowiakowi, Wydawnictwo Polsko-Niemieckie, Warszawa 1999, ss. 134-148.

\section{Rok 2000}

109. Działalność Międzynarodowej Organizacji Pracy na rzecz ochrony praw człowieka, [w:] Ochrona praw człowieka w świecie, red. L. Wiśniewski, Oficyna Wydawnicza BRANTA, Bydgoszcz-Poznań 2000, ss. 149-190.

110. La représentativité des syndicats en Pologne, [w:] Droit syndical et droits de l'homme à l'aube du XXIe siècle. Mélanges en l'honneur de Jean-Maurice Verdier (współautor M. Pliszkiewicz), Dalloz, Paris 2000, ss.113-126.

111. Legal countermeasures against unemployment in Poland during political system transformation, “International Studies" [University of Łódź] 2000, nr 1, s. 51-62. 
112. Measures to counteract discontinuity of employment. Polish case, [w:] L'insécurité de l'emploi, Université Montesquieu-Bordeaux IV, Bordeaux 2000, ss. 279-297.

113. Porozumienia zbiorowe w prawie pracy, [w:] Źródła prawa pracy, red. L. Florek, Liber, Warszawa 2002, ss. 103-117.

114. Problemy statusu prawnego zwiazków zawodowych, [w:] Zbiorowe prawo pracy w społecznej gospodarce rynkowej, red. G. Goździewicz, TNOiK, Toruń 2000, ss. 109-136.

115. Settlement of individual labour disputes in Poland, [w:] Relaciones laborales en el siglo XXI, Universidad Autonoma de Mexico, Mexico 2000, ss. 259-270.

\section{Rok 2001}

116. Konstytucyjne podstawy zbiorowego prawa pracy, [w:] Konstytucyjne podstawy systemu prawa, red. M. Wyrzykowski, Instytut Spraw Publicznych, Warszawa 2001, ss. 81-103.

117. Ocena stanu prawa pracy i jego problemów legislacyjnych, „Przegląd Legislacyjny” 2001, nr 3 (29), ss. 60-127.

118. Studia Prawno-Europejskie, t. V, red. M. Seweryński, Wydawnictwo Uniwersytetu Łódzkiego, Łódź 2001, ss. 160.

119. Załoga zakładu pracy - uwagi de lege ferenda, [w:] Reprezentacja praw i interesów pracowniczych, red. G. Goździewicz, TNOiK, Toruń 2001, ss. 43-61.

\section{Rok 2002}

120. Collective Accords as a source of Law-Validity and Enforceability (Poland, Comment to the Supreme Court, Administrative, Labour and Social Insurance Chamber Decision Decision of 23 May 2001 (2P/100), "International Labour Law Reports" [Kluwer Law International] 2002, vol. 21, ss. 461-464.

121. Employee Involvement and EU Enlargement: Polish Perspective, [w:] Quality of Work and Employee Involvement in Europe, ed. M. Biagi, Kluver Law International, The Hague 2002, ss. 263-277.

122. Podstawowe zasady zbiorowego prawa pracy w prawie europejskim, [w:] Studia Prawno-Europejskie, t. V, red. M. Seweryński, Wydawnictwo Uniwersytetu Łódzkiego, Łódź 2001, ss. 36-50.

123. Poland, [w:] Labour Flexibility and Labour Market, eds U. Carabelli, B. Veneziani, Giuffré Editore, Milano 2002, ss. 179-231.

124. Problemy rekodyfikacji prawa pracy, [w:] Prawo pracy a wyzwania XXI wieku, red. M. Matey-Tyrowicz, L. Nawacki, B. Wagner, Warszawa 2002, ss. 319-338.

125. Społeczne aspekty bezrobocia: skutki i przeciwdziałanie, red. M. Seweryński, Wydawnictwo Uczelniane Akademii Ekonomicznej w Katowicach, Katowice 2002, ss. 158 (współredaktor J. Wojtyła).

126. Studia Prawno-Europejskie, t. VI, red. M. Seweryński, Z. Hajn, Wydawnictwo Uniwersytetu Łódzkiego, Łódź 2002, ss. 239.

127. Système polonais et tendences de la jurisprudence sociale en période de transformations politiques et économiques, [w:] Les juges et le droit social, Comptrasec UMR CNRS, Université Montesquieu Bordeaux IV, Bordeaux 2002, ss. 177-193. 


\section{Rok 2003}

128. Basic Agreements in Poland, [w:] Changing Industrial Relations and Modernisation of Labour Law. Liber Amicorum in Honour of Professor Marco Biagi, eds R. Blanpain, M. Weiss, Kluwer Law International, The Hague 2003, ss. 369-379.

129. Collective Agreements and Individual Contracts of Employment-General Report, [w:] Collective Agreements and Individual Contracts of Employment, ed. M. Seweryński, Kluwer Law International, The Hague 2003, ss. 1-47.

130. Collective Agreements and Individual Contracts of Employment, ed. M. Seweryński, Kluver Law International, The Hague 2003, ss. 251.

131. Contract and Labour Relations - The Polish Case, "Managerial Law" 2003, vol. 45, No 3/4, ss. 119-134.

132. Kontraktualizacja stosunków pracy i jej wpływ na ochrone pracowników, [w:] Godność człowieka, a prawa ekonomiczne i socjalne. Księga Jubileuszowa wydana w piętnasta rocznice ustanowienia Rzecznika Praw Obywatelskich, Biuro Rzecznika Praw Obywatelskich, Warszawa 2003, ss. 97-115.

133. Place centrale du contrat dans les relations de travail en Pologne, [w:] La contractualisation $d u$ Droit Social, sous la dir, de Ph. Auvergnon, Comptrasec, Université de Bordeaux IV, Bordeaux 2003, ss. 145-164.

134. Termination of collective agreements - validity of continuing applicability in certain circumstances (Poland, Comment to the Constitutional Tribunal Decision of 18 November 2002 (K 37/01), International Labour Law Reports, vol. 22, Martinus Nijhoff Publishers, Leiden 2003, ss. 421-425.

\section{Rok 2004}

135. Collective Accords in Polish Labour Law, [w:] Munkajog, Munkaügyi Kapcsolatok. A Harmadik Evezred Kezdeten, Tanulmanyok Dr. Nagy Laszlo, Szeged 2004, ss. 425-438.

136. Employee Involvement in Poland, [w:] Handbook on Employee Involvement in Europe: Poland, Kluwer Law International, The Hague 2004, ss. 1-28.

137. Handbook on Employee Involvement in Europe, eds M. Weiss, M. Seweryński, Kluwer Law International, The Hague 2004.

138. Studia Prawno-Europejskie, t. VII, red. M. Seweryński, Wydawnictwo Uniwersytetu Łódzkiego, Łódź 2004, ss. 332.

139. Uwagi o problemach etycznych procesu edukacyjnego, "Annales Etyka w Życiu Gospodarczym" [Salezjańska Wyższa Szkoła Ekonomii i Zarządzania, Łódź] 2004, t. 7/2, ss. 11-21.

\section{Rok 2005}

140. Collective Agreements in Poland, [w:] Employee Involvement in Globalising World. Liber Amicorum Manfred Weiss, BWV. Berliner Wissenschafts-Verlag, Berlin 2005, ss. 393-402.

141. Problèmes choisis du statut juridique des syndicats en Pologne, [w:] De tous horizons: Mélanges Xavier Blanc Jouvan, Société de législation comparée, Paris 2005, ss. 805-822. 
Wykaz publikacji Jubilata

142. Toward a New Codification of Polish Labour Law, "Labour Law and Policy Journal" 2005, vol. 26, ss. 101-142.

143. Wybrane problemy konstytucyjne kodyfikacji prawa pracy, [w:] Konstytucyjne problemy prawa pracy i zabezpieczenia społecznego, red. H. Szurgacz, Wydawnictwo Uniwersytetu Wrocławskiego, Wrocław 2005, ss. 9-26.

144. Wybrane zagadnienia rozwiazywania sporów zbiorowych w Polsce, [w:] Arbitraż i mediacja w prawie pracy, red. G. Goździewicz, Wydawnictwo KUL, Lublin 2005, ss. 47-70.

\section{Rok 2006}

145. Fundamental Human Rights in the Polish Labour Law (współautor Z. Hajn), [w:] An Era of Human Rights: International Legal Essays in Honour of Jo Carby-Hall, ed. D. Ryland, Barmarick Publications, Patrington, England 2006, ss. 311-339.

146. Politique scientifique de la Pologne dans le contexte de son appartenance à l'Union Européenne, «Annales» 2006, vol. 9 [Centre Scientifique de l'Académie polonaise des Sciences à Paris, Varsovie-Paris].

147. Problemy legislacyjne zbiorowego prawa pracy, [w:] Prawo pracy RP w obliczu przemian, red. M. Matey-Tyrowicz, T. Zieliński, C. H. Beck, Warszawa 2006, ss. 381-435.

148. Studia Prawno-Europejskie, t. VIII, red. M. Seweryński, Wydawnictwo Uniwersytetu Łódzkiego, Łódź 2006, ss. 181.

\section{Rok 2007}

149. Representation of Employees in Collective Bargaining within the Firm, [w:] General Reports on the XVII ${ }^{\text {th }}$ Congress of the International Academy of Comparative Law, eds K. Boele-Woelki, S. van Erp, Bruylant, International Eleven Publishing, The Hague 2007, ss. 603-629.

150. Studia Prawno-Europejskie, t. IX, red. M. Seweryński, Wydawnictwo Uniwersytetu Łódzkiego, Łódź 2007, ss. 204.

\section{Rok 2008}

151. Tożsamość chrześcijańska we wspótczesnej Europie, [w:] Wychowanie w służbie praw człowieka, red. J. Gocko SDB i R. Sadowski SDB, Towarzystwo Naukowe Franciszka Salezego, Warszawa 2008, ss. 13-27.

\section{Rok 2009}

152. Minimalne wynagrodzenie za pracę, [w:] Wynagrodzenie za pracę w warunkach społecznej gospodarki rynkowej i demokracji, red. W Sanetra, Wolters Kluwer Polska Warszawa 2009, ss. 53-62.

153. Porozumienia generalne, [w:] Z zagadnień wspótczesnego prawa pracy. Księga jubileuszowa Profesora Henryka Lewandowskiego, red. Z. Góral, Wolters Kluwer Polska, Warszawa 2009, ss. 79-92. 
154. Społeczna odpowiedzialność pracodawcy, [w:] Społeczna odpowiedzialność biznesu jako źródło sukcesu w województwie śląskim, Publ. NSZZ „Solidarność” - Region Śląsko-Dąbrowski, Katowice 2009, ss. 27-31.

155. Układy zbiorowe pracy w ustroju komunistycznym, [w:] Studia z zakresu prawa pracy i polityki społecznej, red. L. Mitrus, Uniwersytet Jagielloński, Kraków 2009, ss. 473-480.

\section{Rok 2010}

156. Autonomia partnerów społecznych, [w:] Zbiorowe prawo pracy w XXI wieku, red. A. Wypych-Żywicka, M. Tomaszewska, J. Stelina, Fundacja Rozwoju Uniwersytetu Gdańskiego, Gdańsk 2010, ss. 59-68.

157. Ochrona pracowników przed rozwiąaniem umowy o prace wedtug projektu kodeksu pracy, [w:] Ochrona trwałości stosunku pracy w społecznej gospodarce rynkowej, red. G. Goździewicz, Wyd. Oficyna a Wolters Kluwer business, Warszawa 2010, ss. 75-85.

158. Uwagi o efektywności prawa pracy, [w:] Księga pamiatkowa w piata rocznice śmierci profesora Andrzeja Kijowskiego, red. Z. Niedbała, Wolters Kluwer Polska, Warszawa 2010, ss. 271-281.

\section{Rok 2011}

159. Dylematy prawnej ochrony pracy, [w:] Z zagadnień prawa pracy i prawa socjalnego. Ksiega Jubileuszowa Profesora Herberta Szurgacza, Difin, Warszawa 20111, ss. 218-227.

160. Godność pracy człowieka w świetle nauki społecznej Kościoła, [w:] Nauka-Etyka-Wiara 2011, NEW'11, Chrześcijańskie Forum Pracowników Nauki, Warszawa 2011, ss. 329-336.

161. Strategia dla polskiego szkolnictwa wyższego, Seminarium Polskiej Akademii Umiejętności, t. VIII [2009], Kraków 2011, ss. 19-30.

\section{Rok 2012}

162. Działalność publiczna Profesora Lecha Kaczyńskiego, Prezydenta Rzeczypospolitej Polskiej, [w:] Wolność i sprawiedliwość w zatrudnieniu. Księga Pamiatkowa poświęcona Prezydentowi Rzeczypospolitej Polskiej Profesorowi Lechowi Kaczyńskiemu, red. M. Seweryński, J. Stelina, Wydawnictwo Uniwersytetu Gdańskiego, Gdańsk 2012, ss. 7-10.

163. Evolution de la représentation des travailleurs dans l'entreprise en Pologne, [w:] M.A. Moreau (dir.), La représentation collective des travailleurs - ses transformations à la lumière du droit comparé, Dalloz, Paris 2012, ss. 195-207.

164. Pojęcie, zakres i próba kodyfikacji zbiorowego prawa pracy w Polsce, [w:] Aktualne problemy zbiorowego prawa pracy w Polsce i w Niemczech, red. G. Goździewicz, Dom Organizatora, Toruń 2012, ss. 15-25.

165. Wolność i sprawiedliwość w zatrudnieniu. Księga pamiątkowa poświęcona Prezydentowi Rzeczypospolitej Polskiej Profesorowi Lechowi Kaczyńskiemu, red. M. Seweryński (współredaktor J. Stelina), Wydawnictwo Uniwersytetu Gdańskiego, Gdańsk 2012.

166. Zakładowe struktury zwiazkowe w projekcie zbiorowego kodeksu pracy, [w:] Zwiazkowe przedstawicielstwo pracowników zakładu pracy, red. Z. Hajn, Wolters Kluwer SA, Warszawa 2012, ss. 192-202. 


\section{Rok 2013}

167. Kryzys gospodarczy i prawo pracy, [w:] Prawo pracy. Refleksje i poszukiwania, red. G. Uścińska, Instytut Pracy i Spraw Socjalnych, Warszawa 2013, ss. 27-33.

168. Mali pracodawcy w projekcie kodeksu pracy, [w:] Stosunki pracy u małych pracodawców, red. G. Goździewicz, LEX Wolters Kluwer SA, Warszawa 2013, ss. 42-46.

169. Uwagi o przyszłości układów zbiorowych pracy, [w:] Układy zbiorowe pracy. W stulecie urodzin Profesora Wactawa Szuberta, red. Z. Góral, Wyd. Wolters Kluwer SA, Warszawa 2013, ss. 85-92.

170. Wacława Szuberta koncepcja prawa pracy, [w:] Układy zbiorowe pracy. W stulecie urodzin Profesora Wactawa Szuberta, red. Z. Góral, Wyd. Wolters Kluwer SA, Warszawa 2013, ss. 20-35.

\section{Rok 2014}

171. Selected issues of collective bargaining in Poland, [w:] Le travail humain au carrefour du droit et de la sociologie. Hommage au professeur Nikitas Aliprantis, Presse Universitaires de Strasbourg, Strasbourg 2014, ss. 265-271.

172. Social Partners' Autonomy and its Limits, [w:] Autonomie collective et droit du travail. Mélanges en l'honneur du Professeur Pierre Verge, dir. D. Roux, Presses de l'Université Laval, Québec 2014, ss. 351-359.

173. Uwagi o regulacji prawnej wynagrodzenia za prace, [w:] Praca i Płaca. Państwo i Rynek, red, J. Hrynkiewicz, Uniwersytet Warszawski, Warszawa 2014, ss. 33-37.

174. Zakładowy dialog społeczny w projekcie zbiorowego kodeksu pracy, [w:] Zakładowy dialog społeczny, red. J. Stelina, Wolters Kluwer SA, Warszawa 2014, ss. 48-53. 